\title{
Muallim Naci'nin Manzum Hikâyelerinde Kahraman Tipi
}

\section{Hakan DEĞİRMENCI \\ $\ddot{O} z$}

Muallim Naci Efendi, şiir, tenkid, hikâye, makale, mektup, edebiyat tarihi, piyes, hatırat ve deneme gibi edebiyatın hemen her türünde eser vermiş önemli bir sanatçıdır. Şair, münekkit, mütercim ve muallim olan Naci, taşıdı̆̆ı vasıfların hakkını vermiş, kısacık ömrüne pek çok eser sı̆̆dırmayı başarmıştır. Onun manzum hikâyeleri kanaatimizce edebiyat camiasında dahi pek bilinmemektedir. Türk edebiyatında mesneviler üzerinden ilerleyen manzum hikâye yazma geleneği, Tanzimat döneminde, bilhassa ikinci nesilde yer alan sanatçılar sayesinde yeniden canlanmıştır. Destan geleneğinden gelen muhtevaya ilişkin temel, bu dönemde Batı'dan yapılan çevirilerin tesiriyle biçimsel bir dönüşümden geçmiş, böylece manzum hikâyecilik yeni bir inkişaf dönemine girmiştir. Muallim Naci'nin sanatının temelinde, Osmanlı ve İslam tarihi üzerinde yaptığı incelemelerden çıkardığı bilgi ve sonuçların önemli bir yer teşkil ettiği bilinmektedir. Bu çalışmamızda şairin Mûsâ bin Ebü'l Gâzân -yahud- Hamiyyet, Zâtü'n-Nitâkayn -yahudİbnü'z-Zübeyr ve Ertuğrul Gazi Bey isimlerini taşıyan üç manzum hikâyesinde kahraman tipinin nasıl ele alındığını ortaya koymaya çalıştık. Bunu yaparken, geleneksel Türk destanlarındaki tip ve motifleri ve Batı menşeili modern trajedileri de gözönünde bulundurarak mukayeseli bir şekil ve muhteva incelemesi ortaya koymayı da hedefledik.

Anabtar Kelimeler: Tanzimat, Muallim Naci, Destan, Manzum hikâye, Tip

\section{Hero Type in Poetical Stories of Muallim Naci}

\section{Abstract}

Muallim Naci Efendi is an important writer who has worked in almost every genre of literature such as poetry, criticism, story, article, letter, history of literature, play, memoirs and essays. Naci, who was a poet, a translator and a teacher, gave the right to all these qualities he carried, and managed to fit many works in his short life. His poetic stories are not well known even in the literary community in our opinion. The tradition of writing stories in verse, which progressed through the mesnevis in Turkish literature, was revived in the Tanzimat period, especially thanks to the artists of the second generation. The basis of the content coming from the legend tradition has undergone a formal transformation with the effect of the translations made from the West in this period, so verse storytelling has entered a new development period. It is known that Muallim Naci's knowledge and results from his studies on the Ottoman and Islamic history have an important place in the basis of his art. In this study, we tried to reveal how the hero type is handled in the poet's three verse stories named Mûsâ bin Ebü'l Gâzân -yahud- Hamiyyet, Zâtü'nNitâkayn -yahud- İbnü'z-Zübeyr and Ertuğrul Gazi Bey. While doing this, we aimed to present a comparative study of form and content, taking into account the types and motifs of traditional Turkish epics and modern tragedies of Western origin.

Key Words: Tanzimat, Muallim Naci, Epic, Poetry story, Type, Hero

\section{Atıf İçin / Please Cite As:}

Değirmenci, H. (2020). Muallim Naci'nin manzum hikâyelerinde kahraman tipi. Manas Sosyal Araștırmalar Dergisi, 9(4), 2023-2039.

Geliş Tarihi / Received Date: 18.08.2020

Kabul Tarihi / Accepted Date: 23.09.2020

\footnotetext{
${ }^{1}$ Dr. - Türkiye-Aydın Adnan Menderes Üniversitesi Eğitim Fakültesi, hakan.degirmenci@adu.edu.tr ORCID: 0000-0002-1208-6628
} 


\section{Giriş}

Türk edebiyatında manzum hikâyenin köklü bir geçmişi vardır. Edebiyatımızda bilinen ilk manzum hikâye örneği Yusuf Has Hacib’in Kutadgu Bilig'idir (Çıkla, 2009, s. 62). Ondan sonraki Türk şairleri daha çok mesnevî formu içinde bu türün örneklerini vermeye devam etmiştir. Modern Türk edebiyatında manzum hikâye yazma geleneğinin ilk temsilcisi Şinasi'dir. Şiirlerini toplandığı Müntehâbât-ı Eş'âr'da dört manzum hikâyeye yer vermesi bu anlamda dikkat çekicidir. Ne var ki, Tenasüh, Eşek ile Tilki Hikâyesi, Karakus Yavrusu ile Karga Hikâyesi ve Arr ile Sivrisinek. Hikâyesi isimlerini taşıyan bu manzum hikâyelerin (Şinasi, 1960, s. 99-106) üçü fabl türündedir. O hâlde bu eserler üzerinde fazlaca durmaya gerek yoktur. Devam edersek, Şinasi neslinden Namık Kemal ve Ziya Paşa’nın bu türe rağbet göstermemesiyle, manzum hikâye türünde kısa süreli bir durgunluk yaşanmış, ancak daha sonra Recaizâde Ekrem, Abdülhak Hamid ve Muallim Naci Efendi ile beraber bu türde eserler yeniden verilmeye başlanmıştır. Güneş’e göre (2012, s. 9) Türk edebiyatında Servet-i Fünûn döneminden sonra yaygınlaşan manzum hikâyelerde Şark hikâye geleneğinin tesiri olmakla birlikte, manzum hikâyeler üzerinde yapilan incelemeler göstermektedir ki, bu türün inkişaf etmesinde Batı'dan yapılan çeviriler daha tesirli olmuştur.

Destan kelimesi dilimize Farsça'dan geçmiştir. Hikâye, masal, sergüzeşt, manzum hikâye, kıssa, vâkıa, hile, tezvir, tarih, roman, nağme, teganni ve hayvan masalı (fabl) gibi anlamlara gelmektedir (Atsız, 1943, s. 9). Zeki Velidi Togan, destanların milletin yüksek milli duygularını aksettiren halk edebiyatı eserleri olduğunu, tamamıyla veya az çok tarihe dayanan bir ideal âlemi yansıttıklarını ifade etmektedir (1931, s. 4) Geyikoğlu'na göre (2001, s. 201) de destanların tarihteki olaylarla bağlantılı tarafları vardır ve destan metinlerinde, yaşanılan gerçek hayatı tespit etmek mümkündür.

Yukarıdaki tanım ve tespitlerden anlaşılmaktadır ki destan, manzum hikaye, manzum destan kavramları birbiriyle iç içe olan spesifik kavramlardır ve "destan" ile "manzum hikaye" arasında bir tür olarak "manzum destan" diye bir kavram doğmaktadır. Türk edebiyatında destan döneminden itibaren varllğını hissettiren manzum destanlar, Klasik edebiyatta mesnevi ve gazavatnâme, halk edebiyatında ise halk hikâyeleri adıyla varlığını sürdürmüştür. Ancak şïr formunda yazılmış olması ve belirli bir olay örgüsü, şahıs kadrosu, zaman ve mekâna önem vermesinin yanı sıra, ele aldığı mevzular ve onları işleyiş biçimleri bakımından manzum destanları, gazavatnamelerin bir devamı olarak telakki etmek doğru olacaktır. Kazım Yetiş, bazı tanınmış yazar ve şairlerin önemli tarihî olayları yeniden nazma çekerek sunî destan tarzında eserler meydana getirdiklerini belirtir (1994, s. 202). Bunlara örnek olarak Fazıl Hüsnü Dağlarca'nın $\ddot{U}_{c}$ Şehitler Destani'nı, Mehmed Çavuşoğlu'nun Ulubath Hasan Destanı'nı, Yahya Kemal Beyatlı'nın Selimnâme'sini, Mustafa Necati Sepetçioğlu'nun Yaradılıs ve Türeyişini Niyazi Yıldırım Gençosmanoğlu'nun Malazgirt Destani'nı ve Basri Gocul'un üç kitaptan oluşan Ö̆uそlama’sını gösterir. Sözü edilen bu eserlerin hepsini de yukarıda sınırlarını çizdiğimiz kavramları gözönünde bulundurduğumuzda "manzum destan" başlı̆ı altına almak icap etmektedir. Şu durumda pekçok edebiyat araştırmacısının da kullanmaya başladığı üzere "manzum destan" isminde yeni yeni kullanılmaya başlanan bir tür vardır. Bu tür, içerik bakımından destan, şekil bakımından manzum hikâye olarak zuhur etmektedir.

Çalışmamızda ele aldığımız eserlerden Mûsâ bin Ebü'l Gâzân -yahud- Hamiyyet, şekil ve muhteva özellikleri bakımından "manzum destan" tanımına daha çok uymaktadır. Diğer iki eser, Zâtü'n-Nitâkayn yahud- İnnü'z-Zübeyr ve Ertuğrul Gaæi Bey ise "trajedi" türüne yakın durmaktadır. ${ }^{2}$ Nitekim Ahmet Mithat Efendi bir yazısında (1897) Muallim Naci'nin Zatü'n-Nitâkayn ve Ertuğrul Gazi Bey’i Osmanlıca bir trajedi oluşturmak maksadıyla kaleme aldığını belirtir. Tansel'e göre (1962, s. 176) Naci edebiyatımızda klasik bir trajedi çığırı açmak istemiştir ve Zâtü'n-Nitâkayn bu hususta bir denemedir. Kenan Akyüz bir yazısında (1970, s. 182) Zatü'n-Nitâkayn'ı küçük ve manzum bir tarihi diyalog olarak nitelendirirken, Ramazan Kaplan, Naci’nin Ertuğrul Gą̣i Bey eseri üzerine yaptığı bir çalışmasının (1999, s. 135) başlı̆̆ında, bir bilim adamı olarak "trajedi" ifadesini tercih etmekle kendinden önceki görüşlere ittiba etmiştir.

Muallim Naci Efendi'nin hayatı, sanatı ve eserleri üzerinde bugüne kadar yapılmış pekçok çalışma ${ }^{3}$ olsa da, onun ismini yukarıda zikrettiğimiz eserleri üzerinde yeterince durulmamıştır. ${ }^{4}$

\footnotetext{
2 Eserleri kavramsal bir çerçeveye oturtmak bakımından kısaca bu konuya değinmeye lüzum gördük, ancak makalenin özünden uzaklaşmaması bakımından konuyu burada noktalıyoruz.

${ }^{3}$ Muallim Naci ile ilgili ilk etraflıca çalışma, Celal Tarakçı’nın doktora tezidir. (Bkz: Celal Tarakçı, (1973). Muallim Naci Efendi, Yayımlanmamış Doktora Tezi, Erzurum: Atatürk Üniversitesi Sosyal Bilimler Enstitüsü.) Bu tezin bir bölümü üzerine metin ilaveleriyle birlikte yirmi bir sonra 1994'de Kültür Bakanlı̆̆ Yayınları arasında da çıkmıştır. Ne var ki kitaptaki metin ilavelerini çıkarırsak geriye sadece kırk sayfa kadar malumat kalmaktadır. Daha sonra Abdullah Uçman, İnci Enginün, Sema Uğurcan ve Mehmet Tekin'in parçalar hâlinde çalışmalarına rastlanmaktadır. Kanaatimizce Muallim Naci hakkında araştırmacıların malumata
} 
Muallim Naci, 1849 yllında İstanbul'da doğmuş, şiirleriyle genç yaşta edebi muhitlerde dikkat çekmiştir. Asıl ismi Ömer olan Muallim Naci, şiir ve tenkid alanındaki çalışmalarıyla haklı bir üne sahip olmuş bir Tanzimat dönemi sanatçısıdır. Edebiyat tarihlerine hemen daima marjinal bir şahsiyet olarak girmiş bulunan Muallim Naci (Okay, 2005, s. 135), tenkid, hikâye, makale, mektup, edebiyat tarihi, piyes, hatırat ve deneme gibi edebiyatın hemen her türünde eser bırakmıştır. Telif eserlerinin yanı sıra Arapça, Farsça ve Fransızcadan tercüme eserler de vermiş bir mütercimdir. Onun muallim ve gazeteci kimliği de fevkalade mühimdir. Dil ve edebiyatın yanı sıra, eserlerinde medeniyet, tarih, din ve eğitim konularındaki fikirlerini de ifade etmiştir.

Tanzimat devrinin önemli romancısı Ahmet Mithat Efendi'nin damadı olan Naci, 1883'den itibaren Tercümân-ı Hakîkat in edebi sütununu yönetmiş, Recaizâde Ekrem'le olan edebî münakaşalarından sonra arkadaşlarıly birlikte gazeteyi terk etmiştir. Daha sonra birkaç gazetede daha görünen şair, bir süre sonra Mecmûa-i Muallim’i neşr etmeye başlamıştır. Devrin önemli eğitim kurumlarında edebiyat ve Farsça dersleri de veren şair, 12 Nisan 1893'de genç yaşta vefat etmiştir. Ömrünün son dönemlerinde sarayın iltifatına mazhar olan şairin cenazesi Sultan Abdülhamid'in talimattyla Sultan Mahmut türbesinin hazîresine defnedilmiştir.

Bu çalışmamızda bahsi edilen üç eserde kahraman tipinin nasıl ele alındığı üzerinde durulacaktır. Böylelikle eserlerdeki ortaya konan tarihi gerçekliklerin arasında askeri, siyasi, sosyolojik ve psikolojik unsurlar gün yüzüne çıkarılacak ve bunların arasında cesaret, kahramanlık, fedakârlık, namus, şan ve istiklal gibi kavramların nasıl temsil edildiği ortaya konmaya çalışılacaktır. Nitekim destanları bir kahramanın epik biyografisi olarak takip etmemiz mümkündür (Çetindaş, 2014, s. 48).

\section{Endülüs’ün Son Kahramanı: Mûsâ bin Ebü'1 Gâzân -yahud- Hamiyyet}

Endülüs Emevîleri'nin son kumandanı Mûsâ b. Ebü'l-Gāzân'ın savaşlarının ve şehâdetinin dramatik bir dille anlatıldığı bu eser 226 beyitlik bir mesnevidir. Matbaa-i Ebüzziya’da, 1299/1882 senesinde neşredilmiştir.

Endülüs, coğrafi olarak Akdeniz'in batısında yer alan, Avrupa kıtasının güneybatısındaki İber yarımadasında, yani bugünkü İspanya, Portekiz ve Güney Fransa topraklarını içine alan bir bölgenin adıdır. Kelime, ifade ettiği coğrafi sınırların yanı sıra, 8. asıın ilk çeyreğinde Araplar'ın kıtaya çıkışıyla başlayan ve 15. asrin sonlarına kadar devam eden bir Arap-Emevi Devleti'nin tarihini ve bir İslam medeniyetini de karşılamaktadır. Başta Araplar, Osmanlı'dan itibaren Türkler ve bütün İslam dünyası için Endülüs, daima bir şeref ve hüzün sebebi olagelmiştir. Bu bakımdan Araplar'ın bu coğrafyayı ifade ederken "yitik cennet" ifadesini kullanmaları boşuna değildir.

Türk edebiyatında, İspanya’nın fethinde oynadığı role duyulan hayranlıktan dolayı başta Tarı bin Ziyad'n şahsına olmak üzere, bütün bir Endülüs'e merak ve sevginin izleri görülmektedir. Klasik edebiyat döneminden itibaren görülen bu izlerin Tanzimat'tan sonra artarak devam ettiği müşahede edilmektedir. ${ }^{5}$

Tanzimat edebiyatı ile birlikte Batı'yı anlama ve takip etme gayreti içine giren Osmanlı aydınları, Batılı düşünürlerin ve sanatçıların eserlerini incelemeye başlamışlar, bu noktada “İslam'ın terakkiye mani bir din olduğu” tespitiyle karşılaşmışlardır. Buna tepki olarak Batı'nın İslam'a karşı olumsuz bakışına tarih ile cevap vermek yeni Türk edebiyatının genel problematiklerinden birini teşkil etmiştir (Uğurcan, 2002 s. 15). Enginün'ün ifadesiyle (2016, s. 64) tam da bu bağlamda Endülüs medeniyetine sarılmışlar ve Batı'nın İslam karşıtı propagandalarına cevap vermişlerdir. Ayvazoğlu'na göre (1996, s. 81) yapılanlar inkıraz dönemini yaşamakta olan Osmanlı Devleti’nin vaziyeti ile Endülüs'ün "tevâif-i mülûk" dönemi arasında benzerlikler kurup "ibret” dersleri çıkarmaktan ibarettir.

ulaşabilecekleri en geniş ve derinlikli eser, M Kayahan Özgül'ün kitabıdır. (Bkz: M. Kayahan Özgül, (2016). Şïr Haz̧annda Gaz̧el Dökenler-V, Muallim Naci Efendi, İstanbul: Kitabevi).

${ }^{4}$ Bu anlamda sadece üç çalışmadan bahsedilebilir: Bunlardan ilki Ramazan Kaplan'ın ismini daha evvel zikrettiğimiz Ertuğrul Gą̆i manzumesi üzerine yaptığı bir çalışmadır. Bir diğer çalışma ise Alaattin Karaca'nın Mûsâ B. Ebi’l Gâzân makalesidir. (Bkz: Alaattin Karaca, (1992). Muallim Nacinin Mûsâ Bin Ebi'l-Gâzân Yahut Hamiyet Adlı Eseri, Ankara Üniversitesi DTCF Türkoloji Dergisi, X, 143-164). Son olarak M. Kayahan Özgül'ün Muallim Naci üzerine yaptı̆̆ı bir kitap çalışması vardır ki, burada şairin her üç manzumesine de yer vermiştir. Ancak bu çalışmaların tamamında metin transkripsiyonu yapılmıştır. Herhangi bir şekilde günümüz Türkçesine çevirme veya içerikle ilgili bir çalışmaya gidilmemiştir.

5 Ayrıntılı Bilgi İçin Bkz: Abdulsattar Elhajhamed, (2018) 1875’e Kadar Türk Edebiyatında Endülüs, Mukaddime Dergisi, 9, 101-110; Mehmet Ali Gündoğdu, (2016) Abdülhak Hâmid’in Endülüs Ve İlhanlılarla İlgili Piyeslerinde Milletin Birlik Ve Beraberliğinin Önemi, Antalya: 3rd International Congress On Social Sciences, China To Adriatic, 230-242. 
Ziya Paşa, Harâbât adlı eserinde Endülüs şairlerine ve şiirlerine yer vermiştir. Viardot’tan yaptığ1 Endülüs Taribi tercümesinde İslam tarihinin örnek bir dönemi olarak gördügü Endülüs'ü tanıtmış, Endülüs'ü Avrupa medeniyetinin nüvesi olarak göstermiştir. Ziya Paşa'nın bu çevirisinden sonra, Tanzimat yazarları Endülüs tarihinden dönemin sosyal ve siyasî problemlerine çözüm olacağını düşündükleri pek çok dersler çıkarmışlar ve bunları kurgusal eserler içerisinde işlemişlerdir (Gündoğdu, 2017, s. 316). Tanpinar da, Endülïs Taribi tercümesinde yardımcı tercümanın tarih bilgisinden kaynaklanan hatalarına rağmen, zamanında çok tutulduğunu vurgu yaparak, bu eserin Ebüzziya'dan, Muallim Naci'ye kadar, Hamid de içlerinde olmak üzere, mevzuunu Endülüs tarihinden alan birçok eserin doğmasında bir payı olduğunu belirtir (1997, s. 328). Ziya Paşa'nın Endülüs'le ilgili ikinci tercümesi olan Engizissyon Taribinnde ise bölgede yaşayan Müslüman halka yapılan eziyetler ele alınmıştır.

Ziya Paşa'nın bu iki çevirisinden sonra Türk edebiyatında Endülüs'le ilgili yazılan ilk kurgusal metin Şemsettin Sami'nin neşrettiği Seydi Yahya adlı eseridir (Enginün, 2000, s. 38). Şemsettin Sami’nin 1875 senesinde neşrettiği bu eserden iki yıl sonra Vicdan ${ }^{6}$ adlı bir tiyatro metninde de Endülüs'ün son dönemlerini işlediğini biliyoruz. Ancak Endülüs'le ilgili en fazla eser veren sanatçı beş tiyatro eseriyle hiç kuşkusuz Abdülhak Hamid olmuştur.

Muallim Naci Efendi ise devrin yükselen değeri olan Endülüs mevzuuna Mûsâ bin Ebüll Gâzân -yabudHamiyyet adlı manzum hikâyesi ile iştirak etmiştir. Tanzimat dönemi ve Endülüs konularında yoğun çalışmaları olan Gündoğdu, Muallim Naci'nin bu eserde, Ziya Paşa'nın Endülïis Taribi adlı tercümesindeki Musa bahsindeki bilgileri kendine ait bir kurgu içinde tahkiye ettiğini belirtir (2017, s. 319). Nitekim eserin son cildinde Gırnata'nın içine düştügü durum, siyasetçilerin çaresizliği ve basiretsizliği, halkın durumu ve Musa'nın gayreti üzerine uzunca bir bilgi bulunmaktadır (Ziya Paşa, 2004, s. 397-428).

Eser, Abdülhamid devrinde neşredilmesine rağmen, o zaman için söylenilmesi bir cesaret sayllacak fikirleri, yıkılmağa yüz tutmuş bir devlet idaresinin hususiyetlerini, vatanî hisleri aksettirdiğinden mühimdir (Tansel, 1962, s. 171) Recaizâde Ekrem, Mülkiye'deki talebelerine ders olarak okutmuş ve ezberletmiş, tabiata uygun mübalâğalara misal olarak bu eserden bazı parçaları Ta'lim-i Edebiyat'a da almıştır. ${ }^{7}$

Hikâyenin ilk on beytinde İslam'ın Arap toplumu üzerindeki olumlu etkileri üzerinde durulmuştur. Buna göre "Kureyş güneşi" olarak tasvir edilen Hz. Muhammed, karanlıkların arasından bir güneş gibi doğmuştur. Böyle olunca zulümâtın üzerine 1şı1k çökmüş, cehalet karanlı̆̆ı dağılmıştır. Zihinleri aydınlatan ve sineleri nur içinde bırakan o "nur-1 mübîn", kısa zamanda Endülüs halkına da doğru yolu göstermiş,

\section{Etti nûr-ı ruh-ı Resûlallah}

Her dil-i pâki bir tecelligâh

hâline gelmiştir. İlaveten, "Nûr-1 ilim” Endülüs diyarına da aksetmiş, "Zulmet-i cehl” mahvolup gitmiştir. Muhammed'in nuruyla aydınlanan halk, din-i Hakk"1 müeyyed eylemiştir. Zulümât ve nur zıdlığı üzerinden İslam öncesi ile İslam sonrası dönem arasındaki farkı ortaya koyan şair, böylelikle İslam’a tam anlamıla tâbi olmanın önemini vurgulamıştır. Eserin bu ilk bölümünde dikkatleri çeken bir başka husus din-akıl birlikteliğidir:

\section{Akl u dîn ittihâdı âmir idi}

Sö̊ü efrâd-ı milletin bir idi

Neşr-i nûr-ı Mubammed eylediler

Dîn-i Hakker müeyyed eylediler

"Nûr-1 Muhammed", ancak akıl ve din birlikteliğiyle oluşmuştur. Dinin 1şığı ile ilmin nuru bir olunca “din-i hakk"1 müeyyed eylemişler ve Avrupa'nın güneybatısındaki bu büyük yarımadada muazzam bir medeniyet inşa ederek cehaletin karanlığını yenmişlerdir:

Nûr- ilm ol diyâra aks etti

Zulmet-i cebl mahv olup gitti

\footnotetext{
6 İran Morina'nın verdiği bilgiye göre, yakın zamanda Tiran Devlet Arşivi’nde bulunan eserde hürriyet ve vatan sevgisi işlenmektedir. İspanyol işgaline direnen vatansever bir genç kız ile delikanlının aşkı etrafında geçen olayların işlendiği eser, 5 fasıla ve 140 sayfadan oluşmaktadır. (Bkz: İrfan Morina- Salih Okumuş, (2016) Şemsettin Sami’nin Bilinmeyen Bir Tiyatro Eseri: Vicdan, Dede Korkut, 9, 73.)

7 (Akt. Tansel, “Muallim Nâcî’nin Dinî Eserleri”, s. 166) Recaizâde Ekrem, Ta'lim-i Edebiyat, s. 300).
} 
İlerleyen elli beyit boyunca İslam'ın ideal bir devlet ve toplum düzeni için öngördügü ittihat, adalet, ilim ve medeniyet kavramları üzerinde durulmuştur. Burada en çok üzerinde durulan kavram ittihattır. Naci'ye göre Arap'ın İslam üzerindeki sebeb-i inkılabı, ittihat ve sebatıdır. Akıl ve dinin ittihadı da bir başka önemli meseledir. Eğer efrad-1 milletin sözü bir olursa, millet yek-dil olursa bahtiyar olacaktır. Ardından şair sorar:

\section{İttihâd olsa tâb-ı millette}

Hic olur mu zeval millette

Bu kez can alıcı tesbit ve ikazları peş peşe sıralar. Zira:

Ittihâd olmasa vatan yaşamaz.

Çünkü cân olmayminca ten yaşamaz.

Kuvvet ü ižet ittifâk iledir

Za'f u izzet de iftirâk iledir.

Takip eden beş beyitte adalet kavramı üzerinde durulur. Gaza yoluna adl ile girildiğinde, adalet, zaferleri süsleyen bir kavram olmaktadır. Askeri gücün yanına adalet de eklendiğinde

Cok zaman gecmedi silah-ı zafer

Tuttu Ispanya'yz heman yekser

diye uyaran şair ikaza devam eder:

Fethe suret veren adalettir

Ki esas- m muaffakiyettir

Ma'delettir medâr-ı celb-i kulûb

Ma'deletle cihân olur meclûb

İttihat ve adalet gibi en başta gelen iki kavramın yanı sıra, ilerleyen beyitlerde ilim, irfan, hikmet ve medeniyet gibi birbirine nisbeten yakın kavramlar üzerinde de duran şair

Nerde bikmet görürse ehl-i büdâ

Onu almak vazifedir ammâ

şeklinde bir düstur öngörmüş ve fakat bir taraftan da

Avrupa ondan ald irfâm

Bize satmaktader henüz ân

dizeleriyle Arabın içine düştüğü trajediye bir kez daha dikkat çekmiştir. Nihayetinde

Feyz-i meşbûdu mekteb-i edebin

Eser-i ictibâdıdır Arab'in

diyerek edep mektebinin görünen bütün feyzlerinin arkasında yine ittihat ve buradan oluşacak içtihat olduğunu tekrarlamıştır. Kurtuba, tarihteki şöhretli döneminde İslam hükûmetinin bir taht merkezi olmuştur. Zira o dönemde halifeler iyiyi kötüyü ayırt edebilmektedir. Hüneri takdir etme kabiliyetine sahip olduklarından, zekâ ve kabiliyet sahibi olanlar ilerleyebilmektedir. Böylece şanlı günlerde Kurtuba şehri, bilhassa Abdurrahman zamanında fazilet sahibi kişilerin, şairlerin ediplerin ve ilim erbabının diyarı olmuştur. Derken, bürokraside nizam bozulmuş, yeteneksiz kişiler başa geçmiş, "daldıkları zevk denizinde devlet gemisinin nasıl batmakta olduğuna" ehemmiyet bile vermemişlerdir. Hainler işbaşına gelmiş, etraflarını dalkavuklar sarmıştır. Marifet sahipleri birer birer devlet idaresinden uzaklaştırılmış ve günün birinde Emevi Devleti parçalanıp perişan olmuştur:

Bozup ablakı devlet erbâbr

Oldular inkırẫı es esbâbı 
Görüldüğü gibi manzaranın sorumlusu, ahlâkı ve düzeni bozan devlet adamlarıdır. Çok geçmeden düşman harekete geçmiş, kasaba kasaba vatanı işgale başlamıştır:

\section{Mütezelzil olunca pây-i sebât}

\section{Çletı elden birer birer kasabât}

Elde yalnız Gırnata kalmışır. Bu esnada bütün idareciler, başlarında Abdullahu's-Sagir'in veziri Hacib Ebu'l Kasım olduğu halde, El-hamrâ sarayında toplanırlar. Meclisin hâcibi, silah ve teçhizat eksikliğinden, asker sayısının azlığı ve buna mukabil düşmanın çokluğundan söz ederek, düşmandan himaye talep etmekten başka çare olmadığını söyler. O sırada mecliste bulunanlardan askerin en "be-nâm sedârı" Ebu'l Gâzân söze girer ve "milletin savaşmaktan yana olduğunu, el altında yirmi bin askerleri bulunduğunu" söyler. Meclisten şehri müdafaa kararı çıkar, melik de bu karara razı olur. Savaşta Musa büyük kahramanliklar gösterir:

\section{Harbe çıtıkeça kal'adan Mûsâ \\ Dar gelirdi muhâsırîne fez̧â \\ O sokuldukça kal'anm derine}

Bu onu sürdü tâ muaskerine

Rahşı ettiksce dabh ile cevelân

Sirr-l "ve'l-âdiyât" olurdu ayân

Musa muhasara sırasında büyük kahramanlıklar göstermiştir. Ne zaman ki kaleden çıksa gökyüzü düşmana dar gelmiştir. Düşman kaleye sokuldukça, Musa ve askerleri onları kendi karargâhlarına kadar kovalamışlardır. "Gazanfer-i şîrze", düşman ordusunu titretmiştir. Musa'nın atı nefes nefese kaldıkça, âdeta, sure-i Âdiyat'ın hemen başında, nefes nefese koşanlara and içilirkenki sır ortaya çıkmışır:

\section{Müncelî sırr-ı "yabtafü'l-ebsâr"}

\section{Berk-i merdüm-sitâ-yn tîgrndan}

Musa'nın atının tasviri devam etmektedir:

Bilinirdi ne kahraman idüğ̈

Tavr-ı heybet-fezâa-yı rahşından

Rakseder tab'ı şâirân-ı Arab

Cünbüs-i neşve- qâ-yı rahşından

Kılıçların ucu havaya yükseldikçe, Bakara suresinin 20. ayetinde ifadesini bulan "Şimşeğin çakması neredeyse gözlerini alır." sırrı ortaya çıkmışıtır.

\section{Sırr-ı "fe'l-mûriyât" rûsen idi \\ Şerer-i na'l-i pây-i rahşından}

Musa'nın atının ayak nallarında oluşan kıvılcımdan, yine Âdiyat suresinin 2. ayetinde and içilen “tırnaklarıyla kıvılcım saçanlar”a telmihle, bu sırrın aşikâr olduğu belirtilmiştir. İlerleyen mısralarda bu atın "ateş-nümâ" rengiyle "Tûr-1 Mûsâ" yürür gibi salındığından bahisle Musa Peygamber'e telmih yapıllır. Bir epope metinde bir kahramanın atı kadar kilıcı da tasvire ve övgüye layıktır:

Ser-i a'dâya tîgi sâika-bâr

Rabşı ejder-misâl merdüm-bâr

Gamda düssmân belâ-yr tîginden

El-amân-bân salâ-yı tîginden 
Kılıç darbeleri düşman askerlerinin kellesine her inişinde yıldırım çarpması hissi uyandırmakta, ejderha misali insan eti yiyen vahşi bir canavara dönüşmektedir. Kilıç belasından gam içinde kalan düşman, kilıç belasından kurtulmak için el aman dilemektedir. Muallim Naci'nin bu tumturakli, ahenkli ve görsel mısraları, Nefi ve diğer epik şairlerimizin yolundan gittiğini göstermektedir (Uğurcan, 2012, s. 305). Şair, savaş sahnelerinin tasvirini bitirdikten sonra yeniden Musa'ya döner:

Ey emîr-i güzîdesi Arab'in

Simdi sensin dü-dìdesi Arab'in

Hayderin mazhar-ı celâdetisin

Arab'in zübde-i bamiyetisin

Târı'k'a pîşrev olaydin eğer

Şark'tan fethederdi Garb'a kadar

Musa, Arap dünyasının güzide bir emiri, gözbebeğidir. Musa o kadar kahraman bir asker ve büyük bir komutandır ki, ordusunda komutan olsaydı, Tarık bin Ziyad komutasındaki İslam ordusu Doğu'dan Batı'ya kadar bütün cihanı fethedecektir.

Musa'nın bütün gayretine ve kahramanlığına rağmen savaş kaybedilir ve emir Ebu'l Kasım, şehri teslim etmeye karar verir. Musa yeniden söze girer ve 139-187 beyitler arasında ifadesini bulan uzun bir konuşma yapar:

Millete bir terabbum etmez, isek

Ona dïsmen mi merhamet edecek

diye sorar. Musa’ya göre bu hâl tam bir basiretsizliktir ve ardından ikaz eder:

Gecse Grrnata düsmenin yedine

Çan asar en șerefli mabedine

Ne demektir vatan, nedir nâmus

Anlayan kalmamıs, hezâr efsûs

Bu kadar muktedir iken cumbur,

Neden olsun esarete mecbur?

Sonra orada bulunan herkesi yeniden savaşa davet eder:

Edelim hasm müzmabil, geliniz.

Tutmuyor mu killc, tüfek eliniz.

Hasma olsun mu pâymâl benim

Gözlerimden sakındiğgm vatanm

diye sorar ve teklifini yapar:

Yine heybet-nümâ-yi cenk olayım,

Size ben pisşvâ-yi cenk olaym.

Kendimi dâhil-i hisâb etmem;

Çünkü ölmekten ictinâb etmem.

Böyle bir hârî-i milleti çekemem

Ölürüm ben bu zilleti çekemem

Hasma yekten atılmader fikrim

Şühedâya katılmaktır fikrim

Şimdi gönlüm bayâta düşnendir, 


\section{Ölmek elbette bin kat ehvendir.}

Musa'nın millet sevgisi, vatana bağlllık, istiklal ve namus temalarından hepsine birden değinerek yaptığı bu dokunaklı konuşmayı, orada bulunan herkes hayranlık içinde dinler, fakat kimseden ses çıkmaz. Musa anlar ki etrafinda kanı "müncemid" olmuş bu insanlar kendisine "refik" olmayacaktır. Meclisi hiddetle öyle bir terk eder ki:

\section{Ki gören zannederdi kim, bir şî \\ Olmus ol demde ceste-i zincir}

Musa daha sonra bir nehrin kenarına gider, orada soluklanırken ansızın karşıdan düşman askerleri belirir. Yanına yaklaşan birkaç süvari "kim olduğunu ve niçin burada bulunduğunu" sorgular. Cevap alamayınca ona hamle yaparlar. Musa bu ilk saldırıda hepsini yere yıkar. Arkadan yetişen kalabalık gruba karşı da aynı cesaretle karşılık veren Musa, en sonunda aldığı kılıç darbeleriyle dizlerinin üzerine çöker. Elinde kılıcı, yaralarından kanlar boşanırken, son bir gayretle kendini nehre bırakır. Hayatını kaybetmiştir, ancak izzet ve şerefini kurtarmıştır (Karaca, 1992, s. 163). Uğurcan'a göre (2012, s. 305) Müslüman ordusunun su kenarındaki, Şiriş ırmağı galibiyetiyle başlayan Endülüs tarihi, yine su kenarında tek bir hamiyetli adamın ölmesiyle biter. Vakar ve letafet içinde canını teslim eden Musa'nın ağzından dökülen son söz "len terânî" olmuştur. Zira Â'râf suresinin 143. ayetinde, Musa Peygamber Tur dağında "Rabbim bana kendini göster, sana bakayım." Dediğinde, "len terânî", yani "Sen beni göremezsin." cevabını almıştır. Muhtemel ki, Musa son nefesinde bunları tasavvur etmiş yahut yaşamışır. Şair, son iki beyitte:

\section{Düstü Hakk'in mubit-i rabmetine}

\section{Düsmedi düsmenin esaretine}

diyerek Musa’nın seçtiği tarafın yüceliğine vurgu yapmış ve ardından, canını Hak yolunda feda eden Musa için okuyucudan dua istemiştir:

\section{Cânm râh-ı Hak'ta kèldı fedâ}

\section{"Revvehallâbü rûheb̂̀ ebedâ"}

Yahya Kemal, tarihte hiç karşlaşmamamıza rağmen İspanyollara düşmanlık beslediğimizi, buna karşın geçmişte bize pek fenalık eden bazı Slav milletlerini o kadar düşman görmediğimizi tespit eder. ${ }^{8}$ Türkler, önce Tarık bin Ziyad'la fethin coşku ve onurunu yaşamış, Musa'nın destanıyla Endülüs'ün acısını kalbinde bir kez daha duymuştur. Türk edebiyatında eser veren şair ve romancılar halkın taşıdığı bu umumi hisse eserlerinde tercüman olmuşlardır. Ziya Paşa'nın mezkûr tercümesinden itibaren Hâmid ve Sami Paşazâde Sezai'nin piyeslerinde, incelediğimiz bu manzumede, Tanzimat'tan sonra ve Cumhuriyet dönemi boyunca günümüze kadar gelen pekçok eserde bunun izlerini görmek mümkündür.

\section{Bir Kahramanlık Manzumesi: Zâtü'n-Nitâkayn -yahud- İbnü'z-Zübeyr}

1307/1889'da Şirket-i Mürettibiye Matbaası'nda neşredilen manzume, yer yer piyes tarzı bir muhteva taşımaktadır. Manzumenin tarihsel dokusu, Hamiyyet gibi yine İslâm tarihinden, fakat daha eski vak'adan oluşmaktadır. Kahramanları Hazret-i Ebû Bekir’in kızı Esma (Zâtü’n Nitâkayn) ile, torunu Abdullah (İbnüz Zübeyr)'dir.

Hz. Esma, hicret olayında Hz. Muhammed ile Ebu Bekir'e babasına azık hazırlamasıyla meşhurdur. Esma bnt. Ebû Bekir, azıkları bağlayacak bir şey bulamayınca, kuşağını ikiye bölmüş ve bundan dolayı da "Zâtü'n-nitâkayn" yani iki kuşaklı diye adlandırılmıştır. ${ }^{9}$ Muallim Naci, Esma ile oğlu Abdullah'ın hayatını mevzu aldığı eserine bu yüzden Zâtü’n Nitâkayn adını vermiştir. 595 senesinde dünyaya gelen $\mathrm{Hz}$ Esma, Ebû Bekir’in kızı ve Hz. Ayşe’nin ablasıdır. Kocası Zübeyr b. Avvâm, oğlu ise Abdullah b. Zübeyr'dir. Topaloğlu'nun bildirdiğine göre Esma bint Ebî Bekir fetva verecek düzeyde fikıh bilmektedir (1992, s. 250). Yüz seneden fazla yaşadığı bilinen, İslam tarihinde ilmi ve cesaretiyle tanınan Hz. Esma’nın ismi, son olarak Emevi siyasi karışıklıklarında geçer. Hz. Esma, Suriye Emevi ordusunun komutanı Haccac'ın

\footnotetext{
8 Şair, Bir İnkısâr-ı Hayâl başlıklı yazısında, bunun sebebi olarak, İslam tarihinde vaki olan her târizi aynen kendimize ait saymamıza bağlar. Hakikaten de Türk milleti İslamiyet’i bu kadar çok benimsemiştir. Ona göre Türkler'in İslam kardeşliğinden soğumaya başlaması I. Dünya Savaşı'nın ortalarına denk gelmiştir. Zira Mekke Şerifi Hüseyin'in âlâyişli, nümâyişli ihaneti şiddetli bir tesir icrâ etmiş, inkisâr-1 hayâle neden olmuştur. (Bkz: Yahya Kemal, Tarih Musâhabeleri, İstanbul Fetih Cemiyeti Yayınları, İstanbul 1975, s. 100-101)

9 (Akt: Bekir Kuzudişli, (2005) Hadis Rivayetinde Aile İsnadlar, İstanbul: İÜ SBE doktora tezi, s. 103.) İbn Hişâm, Sîre, III, 13; İbn Hibbân, Sikât, III, 23; Beyhakî, Delâil, II, 474; İbn Abdülberr, İstî̂b, IV, 1782; Zehebî, Siyer, II, 288-289.
} 
yürüttüğü Mekke muhasarasında, şehri müdafaa eden bir avuç askerin komutanı olan oğlu Zübeyr ile birlikte bu eserin başkahramanıdır.

505 beyitten oluşan bu uzun manzumenin tamamını incelediğimizde, hikâyenin olay zinciri ile tarihsel olay arasında sıkı bir benzerlik olduğu görülmüştür. Naci’nin İslam tarihi ile ilgili yoğun okumaları olduğu bilinen bir gerçektir.

Manzumenin başında hikâyenin asıl kahramanı Hz Esma'yı tanıtır. İlk beyitte, Esma'nın Ebu Bekir'in kızı ve Zübeyr bin Avvâm'ın refikası olduğu belirtilir. Ardında onun kadınların iftihar vesilesi olduğu vurgulanır. Zira o Sıddık-1 ekberin en büyük kerimesi ve Hz. Ayşe'nin hemşiresidir. Dahası, hicretin ilk senesinde, şerefli bir saatte Tayyibe'de sevimli bir çocuk dünyaya getirmiştir. Esma, Hallak'a şükrân eylemiş, İslam'ın sevinçten mütevellid tekbir sesleri göklere yükselmiştir. Bu çocuğun adı on beşinci beyitte zikredildiği gibi Abdullah, nâm-1 diğer İ̉nü’z-Zübeyr'dir.

Yirmi yedinci beyitten itibaren İslam devletinde yaşanmakta olan siyasi krize geçilmiştir. Kısa bir şekilde o zamana kadar olup bitenin özetlendiği bu bölümde Hz. Ali'nin nuru Hüseyin, Kerbelâ'da düşman askerlerine karşı merdane bir savaş vermiş, fakat hainler tarafindan şehid edilmiştir. Naci bu durumu:

Akerbet gadr ile olunca şebid

Ağladı kâinat, güldï Yęîd

şeklinde ifade etmiştir. Otuzuncu beyitle birlikte yukarıda özetlediğimiz hadisenin haberi Mekke'ye ulaşmıştır. Burada İbnü’z Zübeyr bir hazin hutbe irad eder. Manzumenin 32-76 beyitleri arasinda yer alan bu hutbede, sözlerine "Ey sâkinânı-1 ümm-i kurâ/Gerçi pek doğru söylemez şuarâ" itirafiyla başlayan Zübeyr, devamında Yezid'in ihanetini, yani gösterdiği şiddetli alçaklı̆g ilan ve lanet eder. Devamında Peygambere ve $\mathrm{Hz}$ Ali'ye, sevgi ve sadakatini haykırır. Son olarak da zalimlerin, hiç beklemediği bir anda baş aşağıya dönüvereceğini hatırlatır. Zira Allah, intikam alıııdır. Nice zalimleri ayakaltına alıp çiğnemiştir. O mühlet veren ama asla ihmal etmeyendir. Zübeyr sözlerini birlik ve beraberliğin önemini vurgulayarak tamamlar. Orada bulunan herkes hatibe biat eder; sabır, sükûnet ve mücadele kararı alınır.

Sekseninci beyitten itibaren, Mekke'deki ahvali işiten Yezid, küplere biner ve "farz oldu leşker irsâli" diyerek, bir ordu tekmil eder ve başına Müslim’i geçirir. Orduyu yola çıkarırken de sıkı sıkıya başkomutanı tembihler:

Kim temerrüd ederse i'dam et

Acrma, katl-i âma ikedâm et

Edip İnü'z-Zübeyri der-zincîr

Cânib-i Şâm'a kell heman tesyîr

Doğrudan Medine'ye gidip halkı itaate mecbur kılma talimatı alan Müslim, yoluna kim çıkarsa öldürecek, nihayet Zübeyr’i zincirleyip Şam tarafina sürecektir. Neticede Müslim muvafik olur ve askerleriyle birlikte büyük bir gurur içinde Medine'ye girer. Şehirde katliam ve yağma yapar. Tam askerlerini Mekke üzerine sürmüştür ki iki gün sonra vefat eder. Halefi Hasîn bin Nember, orduyu Mekke'ye sokmayı başarır, şehri talan ederler. Derken Şam'dan Yezid'in öldüğü haberi gelir. Askeri toplayıp hemen Şam'a hareket ederler. İşgalin sona ermesiyle Harem'in sakinleri mesrur olur ve Hakk'a şükrederler.

Manzumenin asıl kısmı 120. beyitten itibaren başlar. Yezid'in yerine geçen İbni Mervan da aynı fikirdedir. Bir gün yüksek bir minberde cemaatin karşısına çıkan Mervan:

Var mı bir er ki Mekke'ye giderek.

Harben İbnü'z-Zübeyri mahvederek

diye sorar. Derken bir zat yerinden kıyam ederek kendini tanıtır ve göreve talip olur. Bu kişi Yusuf oğlu Haccac'trr. Mervan, bu kişiyi küçük görse de görevi ona verir. Askerleriyle yola koyulan Haccac, güzergah üstündeki Taif de kendilerine direnen bir askeri grubu etkisiz hale getirir. Galibiyetin verdiği özgüven ile Mekke'yi almanın kolay olacağını düşünen Haccac, ihtiyata binaen asker takviyesi ister. Mervan bu talebi makul bulur ve muhasara bölgesine beş bin asker daha gönderir. Gerekli asker yardımını ve tam muhasara iznini alan Haccac, büyük bir saldırı başlatır. Mancınıklarla şehri taşlar, Kâbe dökülmeye başlar. Nice masume telef olur. Naci, Haccac'in durumunu "haşre dek oldu seng-i ta'na hedef" diye anlatır. Zamanla 
halk şehri terk etmeye başlar. Kimisi düşmana iltica ederken, kimileri de ar ederek Medine'ye kaçar. Abdullah, burada mertçe meydana çıkar ve gönülden bir kaside okur:

Ey leșker-i sakimü's-siyer

Benim İbnü'z-Zübeyrïn oğlu Zübeyr

Köpeğe ilticâ eder mi peleng

Ederim âlemi köpeklere teng

Bende birdir cevab, o da 'lâ'dr

Bende merdâne ölmek âlâdır

Çekmem ölsem de az'af-ı millet

İki günlük hayat için zillet

Kendini bir kaplana benzeten Abdullah, âlemi köpeklere dar edeceğini, bunu yapamasa da mertçe ölmenin zillet içinde yaşamaktan daha iyi olacağını düşünür. İki günlük hayat için zillete girmeyeceğini de ifade eden kahraman komutan daha sonra kendine seslenir:

Ey Zübeyr, ey peleng-i âhen-çeng

Kal tenezzüul de et kilâb ile ceng

Ona göre demir pençeli bir kaplan için köpek ile ceng etmek olsa olsa tenezzüldür. Daha sonra kilicını sıyırarak havada oynatır:

Haremiyyûna lem'a-i șân ol

Yildrrmlar gibi derabşân ol

Diğer tarafta Zübeyr'i zayıf belleyen Haccac ondan aman dilemesini teklif eder:

Bizden hemân emân-hâh ol

Kalmamıștır halâsa diğer yol

Varsa aklin, edersin istimân

Yoksa hâlin olurdu ânda yaman

Bu son teklif karşısında her ne kadar Zübeyr:

Aržl hâcet eder miyim sana ben

Ben Zübeyr oğhuyum aman dilemem

Öyle alçaksca seyleri bilemem

Ölürüm şân ile zamannda

Yaşamam alçă̆ın emânında

diye cevap verse de, annesi Esma'ya gider, teklifi ona danışır. Manzumenin 238-330. beyitleri arasında anaoğul arasında uzun bir muhavere yaşanır:

Şimdi Haccâc'dan haber geldi,

Demis; Eyyâm-ı terk-i ser geldi,

Durmasin gelsin iltica etsin;

Kendisi bitmeden bu is bitsin!

Vâlidem, işte bâlimiz böyle,

Şimdi re'yin nedir senin, söyle!

diye sorar. Hz. Esma, öncelikle oğlunun vicdanına müracaat etmesini salık verir:

Sö̌ünü dinle ol sübendânm 
'Hakli sensin' diyor mu vicdânın

Zira dünya bir imtihan meydanıdır; Mevla, hayatı güzel bir şekilde noktalamaktan ziyade bir fazilet yaratmamıştır. Allah aşkına vasıl olmak en ziyade neticedir, hüsn ü akıbet buradadır. Esma, sözlerinin sonunda oğluna teslim olmamasını ögütler.

"Bence haketur yolun, devâm eyle

Dâimâ hakekr iltizâm eyle

Yaşamaktan cibanda zillet ile,

Ölmek evlâ değil mi izzet ile?

Kan içinde yuvada da tenini,

Dest-i Haccâc a verme gerdenini!

Matlabın yâ saadet olmalıdır,

Yâ zafer, yâ şshâdet olmahdır!

İki masume birbirine sarılırlar. Zaten Zübeyr de aynı düşüncede olduğu için, mücadeleden vaz geçmemeğe karar verir. Naci bu uzun muhavereden sonra Zübeyr’i meydana salar:

Çıtı meydâna, aldı tekbîrin

Durdu merdâne, çekti şsemşîrin

Manzumenin bundan sonrasında (331-378), meydanda kilıcını çeken Zübeyr, bir iç hesaplaşmaya girer. Cesaret, vatanseverlik ve şehitlik kavramlarını sorgular. Zaman zaman bu iç diyalog dışarıdan, anası Esma yahut bir muhaliften gelen seslerle kesilir. Zübeyr, muhaliflerine hitaben:

Sižler gibi güm-reh değilim, reh-rev-i dînim

Bilmez misiniz ey zalemeİbni Zübeyrim

Terk eylemedim mesleğimi, merd-i metînim

Yok nisbetim İbnül bikem'e, İbni Zübeyrim

derken, anası Esma söze karışır:

Oğlum, yolun âgâh

Zinhâr udûl eyleme, sabr eyle, sabât et

Ecrin verir Allah

Meydanda kahramanca gezinerek coşku içinde söylenen bu sözlerden sonra Zübeyr düşmana doğru hamle yapar. Yanından birkaç ok geçerken namerd hasımlarına kılıç vurmaya başlar. O kadar kahramanca dövüşür ki:

Önüne bir sürü ad̂ิ kattı

Pîş-i tîginde birçoğu yattı

Gayret etmisti savletin teşdîd

Kahr ile kelld cümlesin teb'îd

O besâlet, o siddet-i gayret

Verdi abtâl-ı düsmene hayret

Çatışmanın sonunda Zübeyr'in takati kesilir ve yere düşer. Bu durumu anlatırken "hâtiften bir nidâ" ile Zübeyr'in cezbedâr hallerini (396-400) veren anlatıcı, onun şehadet anını şu beyitle anlatır:

Ederek safvet ürre beyte nigâh

Gitti Bâb-ı Safâ'ya Abdullah 
Düşman askerleri Abdullah'ın başını keserek Haccac'a götürürler. Haccac da bunu "arz-1 hizmet" kabilinden Şam'a gönderir. Esma, defnetmek maksadıyla oğlunun naaşını ister, fakat Haccac buna yanaşmaz. Maksadı yaşlı kadını yalvartmaktır. Esma asil bir tavır sergiler ve 1srar etmez; yine de "kibri bin parça olsun" diyerek Haccac'a beddua eder. Trajedinin sonunda Haccac, naaşı teslim eder. Birkaç gün sonra da yaşlı kadın vefat eder.

\section{Büyük Bir Medeniyet’in Bânisi: Gazi Ertuğrul Bey}

Muallim Naci Efendi’ye “Tarih-Nüvis-i Selâtin-i Âl-i Osman” unvanını kazandıran bu manzume, Hazine-i Fünûn Dergisi’nde 8 Haziran 1310 tarihinde yayımlanmaya başlamış ve neşri 15 Eylül tarihinde tamamlanmıştır. Yayıma başlandığı ilk gün eserin başına Reşad Faik imzasıyla düşülen notta, "bir manzume-i nefise" olarak tanımlanan eserin "Gazi-i müşârünileyhin -pederi Süleyman Şah bin Kaya İlber Firat mi'berinden ubûru esnadamütecerri'-i zülâl-1 gufrân olmasını müteâkib, maiyeti halkıyle diyâr-1 Rum'a geçtikçe ve o aralık Alâeddîn-i Selçukî askerleriyle harb etmekte bulunan leşker-i Tâtâr'ı mağlûb eylediğivak'a-i kahramânâne ve âlî-cenâbânesini muhattır bir levha-i şâirânedir” olduğu belirtilmiştir.

Manzumenin ilk yarısı, asıl konunun işlendiği, -dokusunu tarihsel bir şahsiyetin teşkil ettiği Ertuğrul Gazi’nin anlatıldığ1- bölümün hazırlık kısmıdır. Burada Fırat Nehri manzumenin anlam merkezini oluşturmuştur. Fırat, başlangıçta sade bir nehir iken beyitler ilerledikçe, kurulacak büyük bir medeniyetin arka planı olmaya başlamıştır. Fırat nehri artık bütün bir Türk ve İslam tarihinin hafızası, diğer yandan vaadedilen büyük bir istikbalin mekânıdır. İlerleyen bölümlerde, yani manzumenin ikinci çeyreğinde Türklüğe ve Osmanlıllğa dair işaretler belirmeye başlar. "Halkın babası, biçare yetimlerin ve avare fakirlerin koruyucusu" Süleyman Şah, bu nehri geçerken hayatını kaybetmiş, naaşı Caber Kalesi’ne defnedilmiştir. Yerine, Osmanoğulları'nın kurucusu olacak Osman Gazi'nin babası, mahdumu Ertuğrul Gazi geçmiştir. Arkasında sadece bin aile vardır. Bu kısımlarda Süleyman Şah'ın ölümünden Cengiz sorumlu tutulur. Onun ne kadar acımasız olduğundan bahsedilir. Lakin Ertuğrul gazi farklı düşünmektedir: Ona göre dövünüp yas tutmanın faydası yoktur, Allah’a sığınıp umutsuzluğu bırakmak lazımdır. Ertuğrul Gazi:

\section{Mevlâmiza i'tikadmiz var}

Eltâfina i’timâdımı var

Diye bir kap1 aralar ve halkını mücadeleye davet eder. Manzumenin bundan sonraki kısmında bir hareketlilik görünür ve bu kısımlarda Ertuğrul Gazi’nin kişilik özellikleri iyice belirmeye başlar. Nitekim doksan ikinci beyitle birlikte Tatar ordusu ile Keykubâd'n askerleri arasındaki bir cenge şahit oluruz. Osmanlı iktidarının serdarı olan Ertuğrul derhal bir karar vermek durumunda kalır. İç diyaloglarla geçen bu kısımda büyük serdar şunları düşünür:

Merd olan eyler mi savlet âcize

Yardim etmek galibe düsmez bize

Hayr-bâh-ı âcirân-ı âlemir.

Aciziz bizler de zira âdemiz.

Lâkin oldukça müsâid rü̈gâr

Isteriz âcizlere olmak medâr

derken karar verilir ve tuğlar, kılıçlar göğe yükselir:

Hepsi dă̆ parçası gibi erler

Adim attıkesa titriyor yerler

diyen şair, bu esnada ordunun hep bir ağızdan korkutucu bir avaz ile şu nağmeyi söylediğini aktarır:

Yiğit unvâmmiz.

Yiğitlik sânumı

Zemin meydânmıı

Zaman hatrânımiz. 
Böylelikle savaşta ezeli düşmanlarına karşı Selçuklu askerlerinin yanında yer alan Ertuğrul Gazi ve askerleri, Moğol ordusunu bozguna uğratır. "Mahsul-i azîz-i hüsn-i niyyet" ile başarı kazanan Ertuğrul, iltifat ve şeref kazanır:

\section{Ertugrul'a giydirdi bil'at}

Hil'at o șerefle buldu rif'at

Ardından buradaki zaferin önemi üzerinde durulur. Zira Ertuğrul mağlup olsaydı, Tatar’a esir düşecek ve bütün ümitler yok olacak, Osmanlı'nın adı var olmayacaktır. Bütün bunları “ezeli irâde"ye bağlayan şair, Ertuğrul Gazi'yi seçilmiş bir kul olarak görür. Nitekim:

Allah değil mi kalbe nâžr

Ertuğrul'un kalbi işte bâẓฺ

Bir kalb-i selim var ki onda

Nâdir bulunur eşi cihanda

Ertuğrul'u pîşdâr kılmııs

Te'sîse onu medâr kelmış

Zaten “Kur'an'1 kıble edinmiş, namaz ve diğer ibadetleri âşıkane biçimde edâ eden” Ertuğrul için bunlar şaşılacak şeyler olmamalıdır. Kaplan'a göre (1999, s. 145) burada bölümün temel tezi olan "Osmanlı Devletinin kuruluşu ile ezeli irade arasındaki yakınlık" oluşturulurken, bu tür bir ilişkinin gerektirdiği "dindar Ertuğrul” kişiliği çizmiştir.

Hikâyenin son bölümünde manzumenin olay örgüsüne hiç de uymayan, açıç̧ası biraz eğreti duran bir ekleme ile Sultan Abdülhamid'e övgüler düzülmüştür. Teknik olarak kusur sayılabilecek bu tercihi, şairin o dönemde yaşadığı sosyal ve ekonomik koşullara bağlamak hiç de zor olmayacaktır. Nitekim 1891'de yazılan bu manzumenin Abdülhamit Han tarafindan beğenilmesinden sonra "Tarih-i Nüvis-i Âl-i Osman" unvanıyla kendisine maaş bağlanmıştır (Selâhi, 1310, s. 43). Özgül'ün tespitine göre bu unvan, o güne kadar mevcut olmayan bir unvandır ve Naci, Ertuğrul Gazi'den sonrasını da araştırıp yazacak, manzum bir Osmanlı hanedanı tarihi oluşturacaktır (2016, s. 45).

\section{Sonuç}

Muallim Naci, Türk edebiyatında daha çok şiir, tenkid ve tercüme eserleriyle tanınan bir sanatçıdır. Fakat onun asıl ünü Tercümân-ı Hakîkat in edebi sütununu yönettiği yıllarda Recaizâde Ekrem ile girdiği edebi tartışmalardan gelmektedir. Oysa onun başka türlerde de çalışmaları vardır. Bu çalışmamızda onun pek bilinmeyen üç manzumesi, Mûsâ bin Ebü'l Gâząan -yabud-Hamiyyet, Zâtü'n-Nitâkayn -yabud- İbnü'z-Zübeyr ve Ertuğrul Gaz̧i Bey’ inceleyip, bu eserlerde kahramanlık temasının nasıl işlendiğini ortaya koymaya çalsştık.

$\mathrm{Bu}$ eserlerden ilkinde, Endülüs Emevileri'nin son komutanı olan Musa'nın savaşı ve şehadeti işlenmiş̧tir. Yüzlerce yıl süren bir medeniyetten sonra, devlet gerilemeye başlamış ve nihayet elde sadece Gırnata şehri kalmışır. Manzumenin ilk bölümünde İslam'ın müntesipleri üzerinde nasıl olumlu bir etkisi olduğu anlatılmış, oradan Endülüs'ün yükselişi ve ihtişamlı günlerinden bahsedilmiştir. İttihat, adalet, ilim sacayağı üzerine oturtulan bu büyük medeniyet, yine bu değerlerin yitirilişiyle zayıflamıştır. Zillet ve ihanet batakllğına en başta yöneticilerin düştüğü ülkede genel kanı savaşmadan şehri terk etmekten yanadır. İşte böyle karanlık bir dönemde herkesin tanıdığı şanlı bir komutan olan Musa ortaya çıkar ve şehri canı pahasına savunmaktan yana olduğunu beyan eden tarihten, dinden referanslar yaptığı içinde şeref ve namus gibi değerler taşıyan hamaset dolu bir konuşma yapar. Tek başına şehri savunur ve en sonunda şehit olur.

Zatün-Nitâkayn'da ise bu lakabın sahibi $\mathrm{Hz}$ Ebu Bekir'in kızı, Hz. Ayşe'nin hemşiresi $\mathrm{Hz}$ Esma ile onun oğlu ve Mekke'nin ünlü komutanı Abdullah bin Zübeyr'in namus ve kahramanlık dolu trajedisi anlatılmıştır. 505 beyitten oluşan ve bu şekliyle diğer iki manzumeden hayli uzun olan bu eserin ilk 2/3 lük kısmında ana hikâyeye hazırllk mahiyetinde bilgiler verilir. Kerbela'dan itibaren olup bitenin özetlendiği bu kısımda, zaman zaman ortadaki ihtilafin nedenlerine de değinilmiştir. Asıl hikâyeye gelindiğinde ise Haccac ordusuyla Mekke'ye dayanmıştır. Haftalar süren uzun ve bıktırıcı muhasara, Mekke halkını madden ve manen çözmeye başlamıştır. Mukavemetin son sınırına gelindiği günlerde Haccac son bir kez daha şehri teslim etme önerisini getirir. Başlangıçtan itibaren buna asla yanaşmayacağı belli olan Zübeyr, yine de konuyu bir de annesi Esma'ya danışır. Yaşlı ve bilge bir kadın olan Esma, oğluna şan ve şeref uğruna 
ölmeyi tavsiye eder. Arkasında yeterince askeri kalmayan Zübeyr son bir hamle yaparak şehit olur. Haccac, onun başını keserek Mervan'a gönderir, bedenini şehrin ortasına asar. Esma metanet ve sabır gösterir, en sonunda Haccac, Zübeyr'in defnedilmesine razı olur. Manzumenin sonunda Esma'nın ayağına gelerek olup bitenin muvazenesini yaparlar. Esma burada da asaletinden taviz vermez. Haccac, sessizce ayağa kalkıp arkasına döner ve şehri terk eder. Sadece iki gün sonra Esma da vefat ederek cennetteki oğluna kavuşur.

Konusunu bu kez Türk tarihinden alan Gazi Ertuğrul Bey manzumesinde ise, esere ismini veren Süleyman Şah'ın oğlu ve Osman Gazi'nin babası olan Ertuğrul Bey'in hikâyesi anlatılır. Bu manzumede de ana konuya gelmeden, önce kısaca tarihsel arka plan özetlenir. Süleyman Şah'ın Fırat'ı geçerken vefatı, naaşının Caber Kalesi'ne gömülmesi, diğer taraftan Moğol zulmü gibi hadiseler verildikten sonra Ertuğrul Bey ve arkasındaki bin çadılık boyun verdiği mücadele anlatılır. Savaş sanatı bakımından küçük ama Osmanoğulları'nın kaderini belirlemesi bakımından son derece hayati önem taşıyan bu savaşta, bir grup Selçuklu askeri ile Moğol ordusu arasındaki harbe denk gelen Ertuğrul, kararını verir ve savaşa dahil olur. Manzumenin ana konusu ve gerilimin zirveye yükseldiği yer, Ertuğrul Gazi’nin buradaki kahramanlığıdır. Anlatıcıya göre bu küçük savaş kaybedilmiş olsa Osmanlı devleti hiç kurulamayabilecektir. Sulatan Abdülhamid'e de sunulan ve takdir gören bu manzumeden sonra Muallim Naci Osmanlı hanedanının kalan kısmıyla ilgili destanlar kaleme almaya karar vermiştir. Ne var ki ömrü buna yetmeden, iki sene sonra hayatını kaybetmiştir.

Her üç manzumede öne çıkan birtakım tespitlerimizi, ilaveten benzerlik ya da farklılıklar taşıyan hususları şu şekilde sıralayabiliriz:

1. Din ve ilim, bu ikisini destekleyici mahiyette adalet, ittihat, istiklal ve şeref fikri eserlerdeki temel ve ortak değerlerdir. Ertuğrul Gazi Bey manzumesinde bu değerlerin varllğıyla büyük bir medeniyet kurulmakta, diğer iki eserde ise bu değerlerin yitirilişi ve/veya yokluğu ile medeniyetler yıkılmaktadır. $\mathrm{O}$ halde incelediğimiz manzumelerin üçü de öncelikle öğüt verici birer eserdir.

2. Bütün destanımsı anlatılarda olduğu gibi, bu eserlere de kahramanlarının epik biyografileri gözüyle bakmak gerekmektedir. Ertuğrul Gazi Bey manzumesi, konusunu Türk tarihindeki önemli bir şahsiyetten, diğer ikisi ise konusunu İslam tarihine mâl olmuş kahramanlardan almıştır. Her üç kahraman da sıradan insan değildir. Kendi zamanlarında muteber ve lider kişilerdir. Bir bakıma tarih onlara "atalarına layık olma" sorumluluğu vermiştir. Örneğin, Zâtü'n-Nitâkaynn'da iç monologlarda Abdullah'ın kendisine sık sik "Sen Zübeyr'in oğlusun" demesi boşuna değildir. Buna benzer bir sorumluluk Süleyman Şah'ın oğlu olan Ertuğrul Bey'in omuzlannda da hissedilmektedir.

3. İncelediğimiz üç manzum hikâyede de Türk destanlarının genelinde bulunan bazı ortak tip ve motiflere rastlanmıştır. Manzumelerdeki merkezi kahramanların üçü de "alp tipi"ne uymaktadır. Ta Oğuz Kağan Destanı'ndan beri şahit olduğumuz alp tipi İslam öncesi kullanılmaya başlanmış, İslam'dan sonra kelime “alp-eren”e, Köprülü’nün ifadesiyele de “alp-gazi”ye dönüşmüştür. Bu tipi oluşturan, coğrafi şartlar ve yaşam koşullarıdır. Mehmet Kaplan da, Orta Asya’da geçimini atçlık, hayvancılık ve akıncılık ile sağlayan Türk toplumu için hayatta kalmanın yolu olarak hareket ve kuvveti gösterir. Hasill, alp tipinin en belirgin özelliği olan cesaret ve kahramanlık eserlerimizdeki üç kahramanda da bulunmaktadır. Zâtü'nNitâkayn'daki Esma ise "bilge tipi"ne tam olarak uymaktadır. Esma karakteri bilgisi ve kişiliğiyle topluma önderlik yapan manevi bir tiptir. Her manevi lider gibi o da öğütler vermiş, sözünü dinletmiştir. Oğlunun başı kesilip bedeni meydanda sergilendiğinde dahi metanetini muhafaza etmiştir. Manzumenin son bölümünde Haccac ile girdikleri muhaverede bilgeliğin zirvesine ulaşmıştır. Geleneksel Türk destanlarında ise, kahramanlar umumiyetle kadın sözü dinlemezler.

4. Her epik anlatıda olduğu gibi bu manzumelerde de birçok motif bulunmaktadır. Zâtü'n-Nitâkayn hariç diğer iki manzumede kahramanın etrafinda anlatımı destekleyici mahiyette "at" ve "kilıç" gibi motiflere yer verilir. Nitekim Türk destanlarında alp tipi daima atlıdır. Bu yaşantı Türk düşüncesine "Türk çadırda doğar, at üstünde ölür.” yargısını yerleştirmiştir. Şükrü Elçin’e göre bu yargının temelinde Türk halkının göçebe kültürünün büyük etkisi bulunmaktadır. Kılıç motifi ise at ile birlikte alp tipinin tamamlayıcı aksesuarıdır. Eski Türk destanlarında savaş teçhizatı olarak karşımıza daha çok ok ve yay motifi çıkmaktadır. Fakat bu manzumelerde sadece kılıç ile karşılaşılmışır. Manzumelerde karşımıza çıan bir diğer motif ise "aslan" ve "kaplan"dır. Pekçok kültürde olduğu gibi aslan motifi burada da güç ve asaletin sembolü olarak kullanılmıştır. Kahramanların cesaretle ileri atılmaları ve vazgeçmemeleri aslan; kuvvet ve heybetleri de birkaç yerde kaplan motifiyle ifade edilmiştir. Manzumelerde sıkça karşılaştı̆ıımız bir diğer motif ise "rüya" motifidir. Özellikle Zatü'n-Nitâkayn'da üç yerde rüya vardır ve kahramanlar bu 
rüyalara göre amel etmişlerdir. Bunlardan en etkileyici olanı hiç kuşkusuz Haccac'ın gördüğü rüyadan sonra nedamet duyup Esma’ya günah çıkartmaya gittiği sahnedir.

5. Geleneksel Türk destanlarında Alp kişi savaşa genellikle yalnız girer. Nitekim hem Musa hem de Zübeyr, şehit oldukları çarpışmada tek başlarınadır. Türk destan geleneğinde bazen kahramanın çevresinde kırk yoldaşı bulunur. Ertuğrul Gazi destanında ise kahramanın yanında bin çadır vardır.

6. Musa bin Ebu'l-Gâzân'in soyu ve aldığ1 eğitim hakkında malumat sahibi olamiyoruz ama diğer manzumelerdeki kahramanlar soylu bir aileden gelmiştir. Bu durum, geleneksel Türk destanlarılla benzerlik göstermektedir.

7. Her üç manzumede de hikâye birden bire başlamamış, ana konunun anlatıldığı yere kadar ayrıntılı bir biçimde tarihsel özet sunulmuştur.

8. Manzumelerde gerilim alçalan ve yükselen bir seyir hâlindedir. Dalgalı anlatım özellikle trajedilerde sıkça başvurulan bir anlatım yöntemidir.

9. Hikâyelerde sıklıkla yinelemelere başvurulduğu görülmüştür. Üzerinde hususiyetle durulan bir olay ya da kavrama önem katmak için kullanılan bu teknik, kendini en fazla Zâtü'n-Nitâkayn'da göstermektedir:

Ben Zübeyr oğhuyum, aman dilemem

Öyle alçaksa seyleri bilmem

Ölürüm şân ile zamânında

Yaşamam alçăğn emâninda

Bu mısralar, manzumede iki defa tekrarlanmış, "Ben Zübeyr oğluyum” ifadesi ise en az beş yerde kullanılmıştır. 505 beyitten oluşan bir manzumede bu sayı makul karşılanmalıdır. Yinelemelerin kıvamında kullanılmaması durumu anlatımın kusuru sayılmaktadır, fakat Naci'deki bu mahiyette değildir.

10. Manzumelerde zıtlıklar oluşturulmuştur. Cehalet-ilim, adalet-zulüm, ittihat-ihtilaf, cesaretkorkaklık zıtlıklarına bolca başvurulmasının nedeni kontrast oluşturarak ideal olan düşünceyi berraklaştırmak olmalıdır.

11. Eserlerde ana kahramanların hayat hikâyesinde olağanüstü olaylara ve motiflere rastlanmamıştır. Eski dönemlerdeki destan anlayışının olmazsa olmazı olan "olağanüstülük", modern zamanlarda, bilhassa Batı tarzı trajedinin de tesiriyle yerini "gerçek" olana bırakmıştır.

12. Hülasa, Muallim Naci'nin pek bilinmeyen bu üç manzum hikâyesi, konusunu İslam tarihinde yaşanan gerçek olaylardan alan birer kahramanlık destanıdır. Şair, devrin genel siyasi ve ideolojik atmosferi içinde hareket ederek romantik ve trajik bir iş çıkarmayı denemiş ve bunda büyük ölçüde başarılı olmuştur.

\section{Etik Beyan}

"Muallim Naci'nin Manzum Hikâyelerinde Kahraman Tipi”" başlıklı çalışmanın yazım sürecinde bilimsel, etik ve alıntı kurallarına uyulmuş; toplanan veriler üzerinde herhangi bir tahrifat yapılmamış ve bu çalışma herhangi başka bir akademik yayın ortamına değerlendirme için gönderilmemiştir.

\section{Teşekkür}

Bu makaleyi, akademik hayata başlamama ve sonra yeniden dönmeme vesile olan, Marmara Üniversitesi Yeni Türk Edebiyatı kürsüsünün kıymetli ilim insanlarından Prof. Dr. Muhammet Gür Beyefendi’ye armağan ediyorum.

\section{Kaynakça}

Akyüz, K. (1970). Batı tesirinde Türk şiiri antolojisi. Ankara: Doğuş Matbaacılık.

Ayvazoğlu, B. (1996). Endülïs'ten İspanya'ya. Ankara: TDV Yayınları.

Çetindaş, D. (2014). Yeni Türk şïrinde destan. İstanbul: Ötüken Neşriyat.

Çıkla, S. (2009). Manzum hikâye ve öykü şiir. Türklük Bilimi Araştırmalar Dergisi, 15, 51-58.

Geyikoğlu, H. (2001). Tarih açısından Manas Destanı ve Sovyetler Birliği'ndeki Türklerin milli duygularına etkisi. Atatürk Üniversitesi Türkiyat Araşttrmalar Dergisi, 6, 201-207.

Elçin, Ş. (1963). Atların doğuşları ile ilgili efsaneler. Türk Folklor Araştırmaları, 7.

Enginün, İ. (2000). Abdülhak Hamid'in hatıraları. İstanbul: Dergâh Yayınları.

Enginün, İ. (2006). Yeni Türk edebiyatı Tanżimat'tan Cumburiyet'e. İstanbul: Dergâh Yayınları. 
Gündoğdu, M. A. (2016). Abdülhak Hâmid'in Endülüs ve İlhanlılarla ilgili piyeslerinde milletin birlik ve beraberliğinin önemi. 3rd International Congress On Social Sciences, China To Adriatic. Antalya, 230-242.

Gündoğdu, M. A. (2017). Tanzimat yazarlarına göre Endülüs'ün yık1lış sebepleri. Atatürk Üniversitesi Türkiyat Arastirmalar Dergisi, 58, 315-338.

Güneş, M. (2012). Servet-i Fünun'dan Cumburivet'e Türk Edebiyatında Manžm Hikâye, İstanbul: Hece Yaynları.

Kaplan, M. (2005). Gazi Tipi”, Türk Edebiyatı Üzerine Araștırmalar 3. Tip Tablilleri. İstanbul: Dergâh Yayınlar1, 101-108.

Kaplan, R. (1999). Muallim Naci'nin Bir Trajedi Denemesi, İmi Arastırmalar, 135-146.

Karaca, A. (1992). Muallim Naci'nin Musa Bin Ebi'l-Gâzân yahut Hamiyyet Adlı Eseri, Türkoloji, 143-164.

Köprülü, F. (1331). Selçukîler Zamanında Anadolu'da Türk Medeniyeti, Milli Tetebbûlar Mecmuası, C.II, 201-233.

Köprülü, O. F. (1989). “Alp” Maddesi TDV İslam Ansiklopedisi, C. 2, 525.

Kuzudişli, B. (2005). Hadis Rivayetinde Aile Isnadlar (Doktora Tezi). İstanbul Üniversitesi Sosyal Bilimler Enstitüsü, İstanbul.

Morina, İ. ve Okumuş, S. (2016). Şemsettin Sami’nin bilinmeyen bir tiyatro eseri: Vicdan, Dede Korkut, 9, 71-82.

Muallim Naci (1299). Musa bin Ebu'l Gââan yahud Hamiyed. İstanbul: Matbaa-1 Kütübhâne-i Cihân.

Mualim Naci (1307). Zâtü'n-Nitâkayn -Yahud- İbnü'z-Zübeyr. İstanbul: Şirket-i Mürettibiye Matbaası ve Kütübhânesi.

Muallim Naci (1310). Gaz̨i Ertuğrul Bey. İstanbul: Hazine-i Fünûn Dergisi.

Okay, O. (2005). Batıllaşma Devri Türk Edebiyatı. İstanbul: Dergah Yayınları.

Özgül, M. K. (2016). Şür Hazannda Gaz̨el Dökenler-V, Muallim Naci Efendi. İstanbul: Kitabevi.

Salâhî (1310). Muallim Nâci. İstanbul: Artin Asaduryan Şirket-i Mürettibiye Matbaası.

Şinasi (1960). Müntehâbât-ı Eş’ar (Haz: Beken S.). Ankara: Dün-Bugün Yayınevi.

Tansel, F. A. (1953). Muallim Naci ile Recaizâde Ekrem arasındaki münakaşalar ve bu münakaşaların sebep olduğu edebi hâdiseler. Türkiyat Mecmuası, 10, 159-200.

Tansel, F. A. (1962). Muallim Nâcî’nin Dinî Eserleri, Diyanet İsleri Başkeanliğg Dergisi, 161-177.

Tanpınar, A. H. (1997). 19. Asır Türk Edebiyatı Taribi. İstanbul: Çağlayan Kitabevi.

Tarakçı, C. (1973). Muallim Naci Efendi (Doktora Tezi). Atatürk Üniversitesi Sosyal Bilimler Enstitüsü, Erzurum.

Uçman, A. (2013). Muallim Naci. İstanbul: Toker Yayınları.

Uğurcan, S. (2002). Abdülhak Hamid Tarhan'm Eserlerinde Tarih. İzmir: Akademi Kitabevi.

Uğurcan, S. (2012). Türk edebiyatında Endülüs imajı. Edebiyatımıそ I, Edebiyat-Tarih İlişkisi, İstanbul: Dergâh Yayınları, 299-315,

Yahya Kemal (1975). Tarih Musâhabeleri, İstanbul: İstanbul Fetih Cemiyeti Yayınları.

Yardımc1, M. (2007). Türk destanlarında tipler ve motifler. Destanlar. Ankara: Ürün Yayınları, 50-69.

Yıldız, H. D. (1988). “Abdullah B. Zübeyr B. Avvâm” maddesi, TDV İslam Ansiklopedisi, C. 1, 145-146.

\section{EXTENDED ABSTRACT}

Muallim Naci, one of the important writer and poet of the Tanzimat Period, is a fellow artist who has worked in almost every genre of literature, including poetry, criticism, stories, articles, letters, history of literature, play, memoirs and essays. However, it is in his poems, translated works and criticisms where he gained his reputation. In addition to these three basic areas, there is one more unknown aspect of Muallim Naci: Naci is a poet who also has works in verse story genre. But this aspect of his art for some reason did not get the necessary attention.

The tradition of writing stories in verse dates back to ancient times in Turkish literature. The first example of a verse story in Turkish literature is Yusuf Has Hacib's work called Kutadgu Bilig. The poets that followed continued to give examples of this genre mostly in the form of the mesnevi. The first representative of the tradition of writing verse stories in modern Turkish literature is Sinasi. It is interesting in this sense that he included four verse stories in Müntehâbât-1 Eş'âr, where his poems were collected. However, three of these verse stories are in the form of fables. In that case, there is no need to dwell on these works much. After Şinasi, after Namık Kemal and Ziya Pasha did not show interest in this genre, there was a short-term stagnation in the verse story genre, but later on, together with Recaizâde Ekrem, Abdülhak Hamid and Muallim Naci Efendi, such works started to be given again. In verse stories that became widespread in Turkish literature after the Servet-i Fünn period, the oriental story tradition has an effect, but the studies on verse stories show that the translations made from the West were more effective in the development of this genre.

The word epic entered the Turkish language from Persian. Zeki Velidi Togan means that epics are works of folk literature that reflect the high national feelings of the nation. It is possible to determine the real life lived in epic texts.

Here we understand the following: The concepts of epic, verse story, verse epic are specific concepts that are intertwined with each other and a concept called "verse epic" is born as a genre between "epic" and "verse story". Poetic epics, which have made their presence felt in Turkish literature since the epic period, continued their existence as mesnevi and gazavatnâme in Classical literature and folk tales in folk literature. However, it would be correct to consider verse epics as a continuation of the gazavatnames in 
terms of the issues they deal with and the way they work, as well as being written in poetry form and giving importance to a certain plot, personal staff, time and place. In this case, as many literature researchers have started to use, there is a new genre called "verse epic". This genre appears as an epic in terms of content and a verse story in terms of form.

Among the works we have dealt with in this study, Mûsâ bin Ebü'l Gâzân -yahud- Hamiyyet fits the definition of "poetic epic" more in terms of its form and content features. The other two works, Zâtü'nNitâkayn -yahud- İbnü'z-Zübeyr and Ertuğrul Gazi Bey, are close to the "tragedy" genre. As a matter of fact, Ahmet Mithat Efendi states in one of his articles that Muallim Naci wrote Zatü'n-Nitâkayn and Ertuğrul Gazi Bey in order to create an Ottoman tragedy. Naci wanted to mark a classic tragedy in our literature, and Zâtü'n-Nitâkayn is an essay in this regard. Zatü'n-Nitâkayn can be described as a small and verse historical dialogue, and we prefer the expression "tragedy" for Ertuğrul Gazi Bey's work.

Although there are many studies on the life, art and works of Naci Efendi, there is not enough emphasis on the three works whose names we have mentioned above. Muallim Naci was born in Istanbul in 1849 and attracted attention in literary circles at a young age with his poems. Muallim Naci, whose real name is Ömer, is a Tanzimat period artist who has a well-deserved reputation with his work in poetry and criticism. Muallim Naci, who has almost always entered the literary history as a marginal figure, left works in almost all genres of literature such as stories, articles, letters, history of literature, play, memoirs and essays. He is a translator who has works from Arabic, Persian and French as well as copyrighted works. His teacher and journalist identity is also extremely important. In addition to language and literature, he also expressed his ideas on civilization, history, religion and education in his works. Muallim Naci, who has directed the literary column of Tercümân-1 Hakikat since 1883, left the newspaper of his father-in-law Ahmet Mithat after his literary discussions with Recaizâde Ekrem. The poet, who later appeared in several newspapers, started to publish Mecmûa-i Muallim after a while. The poet, who also taught literature and Persian in important educational institutions of the period, died at a young age in his house in Sarryer on April 12, 1893. The funeral of the poet, who received the compliment of the palace in the last years of his life, was buried in the graveyard of Sultan Mahmut's tomb on the order of Sultan Abdülhamid.

In our study, it will be focused on how the hero type is handled in these three works. In this way, military, political, sociological and psychological elements will be brought to light among the historical realities revealed in the works, and it will be tried to show how sacred concepts such as courage, heroism, sacrifice, honor, glory, independence and future are represented among them. 